\title{
Natural Antimicrobials for Biopreservation of Sprouts
}

\author{
Antonio Gálvez, Hikmate Abriouel, \\ Antonio Cobo and Rubén Pérez Pulido \\ Área de Microbiología, Departamento de Ciencias de la Salud, \\ Facultad de Ciencias Experimentales, Universidad de Jaén, \\ Campus Las Lagunillas s/n. 23071-Jaén \\ Spain
}

\section{Introduction}

In recent years there has been an increase in consumers demands for mungbean, alfalfa, soybean, radish and other seed sprouts (Rosas and Escartin, 2000) that are usually eaten raw in salads or in sandwiches. Seed sprouts have been part of the human diet since old times in countries such as Japan where they are widely consumed. The interest in consuming fresh green sprouts has extended all over the world because they are considered to provide health benefits (Rosas and Escartin, 2000). A great variety of seed sprouts can be found at present in the market, such as adzuki bean (Phaseolus angularis), alfalfa (Medicago sativa), broccoli (Brassica oleracea convar. botrytis), cress (Lepidium sativum), lentil (Lens culinaris), mung bean (Phaseolus aureus), soybean (Glycine max), white mustard (Sinapis alba), green and yellow pea (Pisum sativum), onion (Allium cepa), radish (Raphanus sativus), rice (Oryza sativa L.), rye (Secale cereale), sesame (Sesamum indicum), sunflower (Helianthus annuus) and wheat (Triticum aestivum), although the most popular are alfalfa, soybeans, mung beans and raddish (Taormina et al., 1999). Seed sprouts are usually eaten raw in salads or in sandwiches, and concerns for the safety of these raw foods have increased lately. Sprouts are grown from seeds placed in environmentally controlled, hydroponic conditions and incubated in warm, moist, nutrient-rich conditions, which are ideal environments for microbial growth. The seeds usually carry microbial loads comprised between 3 and $6 \log$ $\mathrm{CFU} / \mathrm{g}$, including pseudomonads and enterobacteriaceae as main components (Andrews et al., 1982; Prokopowich and Blank, 1991; Robertson et al., 2002; Splittstoesser et al., 1983). The bacterial load increases rapidly during the sprouting process, reaching from 6 to 8 log CFU/g after two days in one study (Fu et al., 2001) and between 7.8 and 8.8 in another (Weiss et al., 2007). Other reports have indicated final counts of up to 8-9 log CFU/g in commercial sprouts (Patterson and Woodburn, 1980; Prokopowich and Blank, 1991). In addition, the pathogenic bacteria can survive on sprouts through the typical refrigerated shelf life of the products (Harris et al., 2003). Recent studies indicate that pathogenic bacteria can survive both on and in plant tissues (Lynch et al., 2009). For example, when alfalfa seeds contaminated with Escherichia coli O157 or with Salmonella are sprouted, the bacteria enter the growing sprout, and appear throughout the deep tissues of the young plants (Itoh et al., 
1998; Charkowski et al., 2002). The bacterial cells located inside plant tissue will be refractile to inactivation by common disinfection methods.

A wide variety of pathogens have been isolated from sprouted seeds (including alfalfa, mung bean, cress, soybean, and mustard): Aeromonas hydrophila, Salmonella spp., Listeria monocytogenes, Staphylococcus aureus, Bacillus cereus, Yersinia enterocolitica and Vibrio cholerae (Beuchat, 1996; Harris et al., 2003). Outbreaks have been associated primarily with Salmonella serotypes but have also been attributed to B. cereus, E. coli O157:H7, and Y. enterocolitica (Harris et al., 2003). Alfalfa sprouts rank in the first place of associated outbreaks, followed by far by clover, radish, and mung bean sprouts. This is due to the fact that alfalfa sprouts are the most popular type of seed sprouts that are commonly eaten raw, while others such as mung beans are often cooked before consumption. Therefore, it is necessary to plan intervention strategies to decrease the risks for transmission of human pathogenic bacteria through sprouted seeds. In this chapter we discuss how different biocontrol strategies can be applied either alone or in combination with other intervention strategies to improve the control of pathogenic bacteria most frequently found in sprouts (Fig. 1).

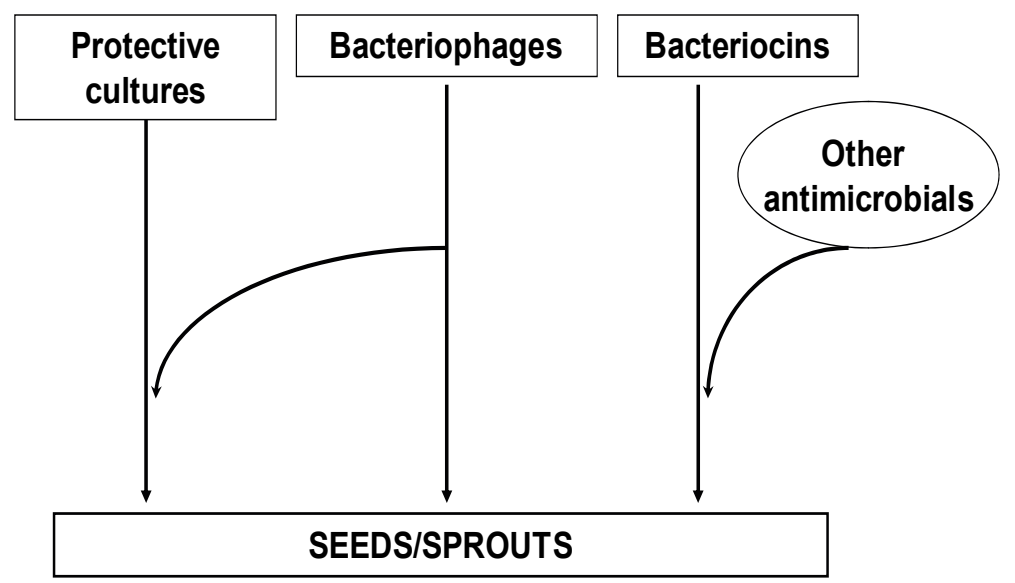

Fig. 1. Intervention strategies based on biopreservation to decrease the risk of transmission of human pathogenic bacteria in sprouts.

\section{Inoculation with protective cultures}

One of the oldest approaches for biopreservation of foods is based on the natural interactions that microbes play in Nature. Such interactions can be redirected and exploited to selectively inhibit microbial populations of concern, such as pathogenic or spoilage bacteria in food ecosystems. Microbial antagonism is usually based on a combination of mechanisms which include competition for space and nutrients, and selectively changing the environmental conditions, eg. by acidification, or production of an array of antimicrobial substances that include organic acids, oxygen radicals, siderophores, antibiotics, lytic enzymes, and bacteriocins. The bacteriocins were defined by Jack et al. (1995) as ribosomally synthesized antimicrobial peptides or proteins. When using live microbial antagonists as protective cultures in food biopreservation, there is a number of limitations and rules that need to be taken into consideration (Galvez et al., 2007): i) the protective cultures must not 
be pathogenic or produce toxins against humans or animals, and must not modify the organoleptic properties of the food product; ii) they must be able to multiply in the food and produce antagonistic activity at the food storage temperature; ii) they must be efficient in controlling the bacterial pathogen of concern under the common food storage and processing conditions.

There has been a great interest in the application of bacteriocins and bacteriocin-producing strains (especially those produced by the LAB) on the preservation of foods of animal origin, but to a much less extent on vegetable foods such as sprouted seeds (Gálvez et al., 2008; Abriouel et al., 2010). Cai et al. (1997) isolated a collection of bacteria from mung- and soy bean-sprouts from retail stores and tested them for anti-listerial activity. Ten strains showed highest inhibitory activity, among which one strain was identified as a nisin-producing Lactococcus lactis subsp. lactis. This strain was able to reduce the levels of L. monocytogenes by 1.0-1.4 logs in Caesar salad after storage for 10 days at 7 or $10^{\circ} \mathrm{C}$. Similar results were reported when the bacteriocin-producing Enterococcus faecium ATCC 19434 strain was tested on the salad for comparison (Cai et al., 1997). However, none of the strains were tested on sprouts. The enterococcal strain Enterococcus faecalis A-48-32 (which produces the cyclic peptide bacteriocin AS-48) was inoculated as a protective culture against $B$. cereus on soybean sprouts stored at 15 and $22{ }^{\circ} \mathrm{C}$ simulating temperature-abuse events (Cobo Molinos et al., 2008a). Enterococci multiplied rapidly on sprouts at the two temperatures tested. In both cases, bacteriocin activity could be recovered from the sprouts during days 1 to 3 of storage, but not after more prolonged periods. In cocultures at $15{ }^{\circ} \mathrm{C}$, growth of $B$. cereus was completely inhibited for the whole storage period, with viable cell counts being significantly lower than control cultures for the first 5 days of storage. By contrast, cocultivation with the A-48-32 strain at $22{ }^{\circ} \mathrm{C}$ only produced some growth inhibition of $B$. cereus during the first 3 days of storage.

Bennik et al. (1999) tested two bacteriocin-producing Pediococcus parvulus strains (isolated from minimally-processed vegetables and one Enterocococcus mundtii ATO6 strain (isolated from chicory endive) that produced the pediocin-like mundticin ATO6 (Bennik et al., 1998). Only E. mundtii was capable of bacteriocin production at $4-8^{\circ} \mathrm{C}$, a reason why this strain was selected for experiments to control L. monocytogenes on mungbean sprouts, which were stored under modified atmosphere (MA) of $1.5 \% \mathrm{O}_{2} / 20 \% \mathrm{CO}_{2} / 78.5 \% \mathrm{~N}_{2}$ at $8{ }^{\circ} \mathrm{C}$. However, in spite of its capacity for growth and bacteriocin production under MA, this strain failed to inhibit the growth of L. monocytogenes on sprouts and for this reason was not likely to be feasible for application as a protective culture (Bennik et al., 1999). More recently, the bacteriocin-producing strain E. mundtii CUGF08 isolated from alfalfa sprouts was shown to produce an anti-listerial bacteriocin called mundticin L (Feng et al., 2009). This bacteriocin is highly similar to mundticin ATO6, differing in only by one amino acid residue in the YYGNGV (YYGNGL) motif and the last two amino acid residues, which are reversed as in the almost identical mundticin SK (Kawamoto et al., 2002). The antagonistic capacity of this strain on sprouts has not been reported so far.

In one study, approximately 120 strains of indigenous microbiota from raw vegetables (including alfalfa and clover sprouting seeds, Romaine lettuce, and pre-peeled baby carrots) were tested for their ability to inhibit the growth of Salmonella Chester, L. monocytogenes, E. coli, or Erwinia carotovora subsp. carotovora (Liao and Fett, 2001). Six isolates capable of inhibiting the growth of at least one pathogen were isolated and identified: Bacillus spp. (three strains), Pseudomonas aeruginosa (one strain), Pseudomonas fluorescens (strain A3), and yeast (strain D1). When strains A3 and D1 were tested on green pepper, the growth of Salmonella Chester and L. monocytogenes was reduced by 1 and 2 logs, respectively, over a 
period of 3 days. The authors stressed the potential of these two strains as biocontrol agents for reducing the growth of these two pathogens on fresh produce products, although their inhibitory effects on sprouts were not determined.

Matos and Garland (2004) tested different potential biological control inoculants against Salmonella in alfalfa. Inocula included raw bacterial suspensions derived from market sprouts or laboratory-grown alfalfa sprouts (obtained by sonication of sprouts in a buffered peptone solution) and the $P$. fluorescens 2-79 strain. This strain was originally isolated from the rhizosphere of wheat and shown to suppress take-all, a major fungal root and crown disease of wheat and barley. A cocktail of four different serovars of Salmonella were used, all of them isolated from sprout-related outbreaks (Salmonella Newport H1275, Salmonella Anatum F4317, Salmonella Stanley H0558, and Salmonella Infantis F4319). According to results of the competitive exclusion bioassays, $P$. fluorescens 2-79 was able to reduce the growth of Salmonella on alfalfa sprouts by 4.22, 4.24, and $1.81 \operatorname{logs}$ on days 1, 3, and 7, respectively. The laboratory-grown sprout inoculum also had its highest inhibitory effect on Salmonella at the beginning of the growth period with $\log$ reductions of 2.56 on day 1; however, viable cell reductions then decreased to 0.21 on day 3 and $0.71 \operatorname{logs}$ on day 7 . The best results were observed for the market sprout inoculum, which reduced the number of Salmonella cells by 1.61, 2.80, and $5.48 \log$ on days 1,3 and 7, respectively. The market sprouts inoculum achieved the highest log reduction of Salmonella on day 7 than any of the other experimental treatments. Apparently, the natural populations of bacteria found in commercial sprouts were better adapted to utilization of an array of nutrient substrates, suggesting competition with the Salmonella for available resources as a potential mode of action. Unfortunately, the authors did not characterize the microbial composition of this inoculum or how it could be propagated and standardized as a commercial inoculant.

The potential of $P$. fluorescens $2-79$ as a biocontrol agent on sprouts was further investigated by Fett (2006). The addition of a $P$. fluorescens 2-79 inoculum to the seed soak water prior to the germination of alfalfa seeds previously inoculated with a cocktail of Salmonella enterica strains led to outgrowth inhibition of the salmonellae through the complete 6-days sprouting period, without an adverse effect on sprout yield or appearance. At day 6, the counts of S. enterica were between 4 and $5 \log \mathrm{CFU} / \mathrm{g}$ lower compared to seeds not treated with the antagonist. Final cell numbers of $S$. enterica on the sprouted seeds were shown to be dependant on the cell density of the inoculum and on the application or not of a sanitation treatment (Liao, 2008). Remarkably, the population of salmonellae on sanitized seeds was approx. $1 \log$ higher than that on nonsanitized seeds which contained 2 logs higher number of native microflora. In another study, a Pseudomonas jessenii strain isolated from raddish sprouts showed high inhibitory activity against a variety of target bacteria (L. innocua, S. aureus, Bacillus subtilis, S. Typhimurium, E. cloacae and other Pseudomonas strains). When tested as a protective culture in challenge experiments against $S$. Senftenberg on hydroponically grown mung bean seeds inoculated simultaneously with the two bacteria, Salmonella showed a reduced growth on the sprouts, which resulted in cell counts exceeding $3 \log$ and $2 \log$ CFU/g below the control after 24 and $48 \mathrm{~h}$ incubation, respectively (Weiss et al., 2007). The best results were obtained when the seeds were preinoculated with $P$. jenssenii on day 0 and challenged with Salmonella Senftenberg on day 1 of sprouting. Pre-inoculation with $P$. jenssenii completely suppressed growth of $S$. Senftenberg during germination of sprouts. After 7 days, while the salmonellae reached $8 \mathrm{log} C F U / g$ in the control samples, counts on sprout samples with the pre-treated seeds were below $1 \log \mathrm{CFU} / \mathrm{g}$. 
Enterobacter asburiae is commonly associated with plants and has been used as a biocontrol strain for inhibiting the growth of enteric pathogens such as Salmonella and E. coli O157:H7 (Cooley et al., 2003). E. asburiae JX1 isolated from mungbean sprouts exhibited stable antagonistic activity against a broad range of Salmonella serovars (Agona, Berta, Enteritidis, Hadar, Heidelberg, Javiana, Montevideo, Muenchen, Newport, Saint Paul, and Typhimurium DT104) (Ye et al., 2010). Mung beans inoculated with a cocktail of the Salmonella serovars in combination with E. asburiae JX1 attained much lower levels of salmonellae (1.16 log CFU/g) than the single cocktail inoculated samples (6.72 log CFU/g) after 4 days of sprouting. The inhibitory activity of E. asburiae JX1 was attributed partially to nutrient competition, but also to the production of inhibitory substance(s) released in solid medium but not in liquid cultures.

\section{Application of lytic bacteriophages}

Lytic bacteriophages are gaining interest as biocontrol agents because they are highly species-specific, and therefore can target the pathogenic bacteria of concern without affecting other bacteria that may be of interest in the particular food system where they are being applied. The self-propagating capacity of lytic bacteriophages is also an advantage concerning the amount of inoculant to be added, decreasing in principle the processing costs. Phages have been shown to control the growth of pathogens such as L. monocytogenes, Salmonella and Campylobacter jejuni, as well as spoilage organisms in fruit, dairy products, poultry and red meats (Greer, 2005; Hudson et al., 2005; Rees and Dodd, 2006). Nevertheless, due to their high strain specificity, it is often necessary to apply complex phage mixtures, making the phage selection procedures rather complicated. Factors such as strain sensitivity, transient resistance, and host range specificity of the bacteriophages clearly seem to limit their application as biocontrol agents on sprouts.

Pao et al. (2004) tested the potential of lytic phages (the Myoviridae Phage-A, targeting Salmonella Typhimurium and Salmonella Enteritidis, and the Siphoviridae Phage-B, specific for Salmonella Montevideo) in experimentally contaminated broccoli and mustard seeds. Salmonella counts increased to a greater extent in mustard seeds than in broccoli seeds during soaking. Application of Phage-A achieved a 1.37 log suppression of Salmonella growth on mustard seeds. The mixture of Phage-A and Phage-B caused a $1.50 \mathrm{log}$ suppression of Salmonella growth in the soaking water of broccoli seeds. Because of the observed host specificity of phages, the authors stressed the importance of developing phage mixtures that can control a broad range of potential contaminants. However, experiments with two Salmonella bacteriophages isolated from enrichment of sewage samples (SSP5 and SSP6, belonging to the Myoviridae and Siphoviridae families, respectively) against a Salmonella Oranienburg strain (isolated from an outbreak of salmonellosis associated with alfalfa sprouts in Australia) provided unsatisfactory results. In liquid cultures, maximum reductions of Salmonella counts of ca. 1 log unit were achieved after $3 \mathrm{~h}$ of incubation. However, the remaining viable population was refractile to a second bacteriophage addition, entering a temporary non-specific phage resistance stage (Kocharunchitt et al., 2009). The temporary character of resistance was further demonstrated because bacterial colonies isolated from agar plates after the phage challenge showed the same degree of phage sensitivity as the original strains. On alfalfa seeds experimentally contaminated with S. Oranienburg, phage treatment (SSP6) caused a still lower reduction of Salmonella levels after $3 \mathrm{~h}$ of presoaking (as compared to liquid cultures) and did not inhibit 
growth of the Salmonella population thereafter. The phage survived on both treated and control seeds as well as in their treatment solutions, indicating that the phage could survive throughout the sprouting process.

In a more recent study, a cocktail of six bacteriophages (F01, P01, P102, P700, P800, and FL 41 ) isolated from manure effluent sampled from pig or feedlot farms was prepared and evaluated for controlling a cocktail of Salmonella serovars in sprouting seeds (Ye et al., 2010). Mung beans inoculated with Salmonella and sprouted over a 4-day period attained levels of $6.72 \mathrm{log}$ CFU/g. Levels of Salmonella were reduced to $3.31 \mathrm{log}$ CFU/g when the pathogen was coinoculated with bacteriophages. However, by using a combination of E. asburiae JX1 and bacteriophages, the levels of Salmonella associated with mung bean sprouts were only detected by enrichment. With alfalfa sprouts derived from seeds inoculated with Salmonella alone, the counts of the enteric pathogen attained levels in the order of $7.62 \log \mathrm{CFU} / \mathrm{g}$. However, in the presence of E. asburiae JX1 and bacteriophages, no Salmonella was recovered even when samples (25-g batches) were enriched. The biocontrol preparation was effective at controlling the growth of Salmonella under a range of sprouting temperatures (20 to 30 $\left.{ }^{\circ} \mathrm{C}\right)$. The combination of E. asburiae JX1 and bacteriophages represents a promising, chemical-free approach for controlling the growth of Salmonella on sprouting seeds.

\section{Treatment with bacteriocin preparations}

Bacteriocins can be concentrated from cultured broths of their producer strains and used as partially-purified preparations in food systems. Nisin and pediocin PA-1/Ach are available on the market for application in foods. These convenient, natural preservatives, can be added to foods in a more flexible way than protective cultures or phage preparations, and the bacteriocin dose can be adjusted to maximize its bactericidal effects. Very often, bacteriocins are used in food systems as part of hurdle technology, whereby their bactericidal effects are enhanced by other antimicrobial factors with which they may act synergistically.

Compared to meat and dairy products, where the application of bacteriocins has been studied extensively, much less work has been done on vegetable foods. In mungbean sprouts dipped in a solution of purified mundticin ATO6 $(200 \mathrm{U} / \mathrm{ml})$ or coated with an alginate film containing the bacteriocin $(200 \mathrm{U} / \mathrm{ml})$, a 2 log-decline of listerial counts was observed after treatments (Bennik et al., 1999). Although outgrowth of the listeria was not inhibited during storage of samples, counts obtained for the mundticin-treated samples were always lower compared to the untreated control. The mundticin-alginate coating provided the best results, especially within days 5 and 10 of incubation. Application of bacteriocins immobilized in edible coatings has been investigated in greater details for other types of foods. Bacteriocin immobilization has several advantages like a more regular delivery of bacteriocin molecules to the food substrate, lower inactivation of bacteriocin by interaction with food components or enzymes, and protection from cross contamination.

Nisin and pediocin solutions were tested as possible sanitizer treatments on cabbage, broccoli, and mung bean sprouts against a bacterial cocktail of five L. monocytogenes strains (Bari et al., 2005). Two hours after inoculation of the listeria, the samples were washed vigorously with agitation for $1 \mathrm{~min}$ with different antimicrobial solutions (0.02 M EDTA, 2\% sodium lactate, $0.02 \%$ potassium sorbate, $0.02 \%$ phytic acid, $10 \mathrm{mM}$ citric acid, and $50 \mathrm{mg} / 1$ of nisin, $48 \mathrm{mg} / 1$ of pediocin, or combinations of bacteriocins and chemical preservatives). Viable cell count determinations after treatments indicated an overall lower efficacy for all 
treatments on mung bean sprouts compared to the other vegetable substrates, resulting in reductions of $0.5 \mathrm{log} \mathrm{CFU} / \mathrm{g}$ or lower compared to samples washed simply with distilled water. Antilisterial activity of pediocin in sprouts was potentiated by citric acid, while the activity of nisin was by phytic acid. The most effective antimicrobial treatment combination on mung bean sprouts was nisin plus pediocin plus phytic acid, which caused a 1.2-log $\mathrm{CFU} / \mathrm{g}$ reduction compared to washing treatment with distilled water. This combined treatment also reduced the native microflora by ca $1.4 \log \mathrm{CFU} / \mathrm{g}$. However, the fate of survivors after treatment was not investigated. It would be interesting to know whether the surviving bacterial populations were able to multiply or decreased during further storage of the treated samples.

Enterocin AS-48 is a broad-spectrum cyclic antimicrobial peptide produced by $E$. faecalis and E. faecium strains (reviewed by Maqueda et al., 2004). This bacteriocin has been widely investigated in food systems against foodborne pathogenic bacteria such as L. monocytogenes, $S$. aureus, B. cereus, E. coli or S. enterica (Abriouel et al., 2010; Ananou et al., 2005; Cobo Molinos et al., 2005, 2009a; Grande et al., 2006, 2007a, b; Martínez Viedma et al., 2008, 2009a, 2009b; Muñoz et al., 2007). Partially-purified preparations of enterocin AS-48 can be produced easy on semi-synthetic media (Abriouel et al., 2003) and on whey-based substrates (Ananou et al., 2010), which makes this bacteriocin an amenable antimicrobial for application in foods. Because of its broad spectrum of inhibition and increased stability due to its cyclic structure, enterocin AS- 48 can be a sound candidate for decontamination of vegetable foods containing L. monocytogenes and other foodborne bacteria sensitive to this bacteriocin.

In experiments carried out for enterocin AS- 48 on sprouts, L. monocytogenes was able to grow without bacteriocin on alfalfa and soybean sprouts and in green asparagus at temperatures of 6 to $22^{\circ} \mathrm{C}$ and to reach high cell numbers (up to $6 \log \mathrm{CFU} / \mathrm{g}$, depending on temperature) during storage (Cobo Molinos et al., 2005). Sprouts inoculated with L. monocytogenes were treated by immersion for $5 \mathrm{~min}$ in distilled water or in bacteriocin solutions of $5,12.5$, and 25 $\mu \mathrm{g} / \mathrm{ml}$. The effect of bacteriocin treatment was directly proportional to bacteriocin concentration and inversely proportional to storage temperature of samples after treatment. In alfalfa and soybean sprouts, the concentration of viable listeria was reduced by approx. 2 $\log$ units by the $25 \mu \mathrm{g} / \mathrm{ml}$ bacteriocin immersion treatment. Washing treatments with 12.5 $\mu \mathrm{g} / \mathrm{ml}$ bacteriocin caused apparently much lower reductions of listeria populations in soybean sprouts compared to alfalfa sprouts (1-1.5 log cycles). Nevertheless, for both alfalfa and soybean sprouts, the bacteriocin concentrations of 12.5 as well as $25 \mu \mathrm{g} / \mathrm{ml}$ reduced the concentrations of viable listeria below the detection levels from day 1 to day 7 of storage at temperatures of $6^{\circ} \mathrm{C}$ as well as $15^{\circ} \mathrm{C}$. These results indicated that residual bacteriocin adsorbed to the treated sprouts was able to provide a protective effect after treatment for samples stored under a broad interval of refrigeration temperatures (Cobo Molinos et al., 2005). Nevertheless, incubation of the treated samples at a higher temperature of $22^{\circ} \mathrm{C}$ seriously compromised the protective effect of the bacteriocin. In soybean sprouts, the concentration of viable cells was reduced much more slowly, and in alfalfa sprouts the listeria were able to multiply even in the samples treated with $25 \mu \mathrm{g} / \mathrm{ml}$ bacteriocin. For green asparagus, no viable listeria were detected during storage at $15^{\circ} \mathrm{C}$ of samples treated with bacteriocin concentrations of 12.5 and $25 \mu \mathrm{g} / \mathrm{ml}$. The bacteriocin apparently had a lower effect at $6^{\circ} \mathrm{C}$ (reducing the viable concentration of listeria below detection levels only for $25 \mu \mathrm{g} / \mathrm{ml}$ bacteriocin after day 3 of storage) and did not avoid growth of the listeria in the samples stored at $22^{\circ} \mathrm{C}$. 
In order to improve the bactericidal effects against listeria, the bacteriocin $(25 \mu \mathrm{g} / \mathrm{ml})$ was applied on green asparagus in washing treatments in combinations with a variety of antimicrobials: acetic acid, citric acid, lactic acid, potassium lactate, sodium propionate, potassium sorbate, sodium nitrite and nitrate, trisodium-tri-metaphosphate, potassium thiosulfate, potassium permanganate, $\mathrm{n}$-propyl $p$-hydroxybenzoate, $p$-hydoxybenzoic acid methyl esther, hexadecylpyridinium chloride, peracetic acid, and sodium hypochlorite (Cobo Molinos et al., 2005; Table 1). The combinations of AS-48, acetic acid, citric acid, sodium propionate, potassium sorbate or sodium nitrite had limited or no effect on viability of listeria compared to the effect of AS- 48 alone. Remarkably, solutions containing AS- 48 plus lactic acid $(0.1 \%$ and $0.5 \%)$, sodium lactate $(0.1 \%$ and $0.5 \%)$, n-propyl phydroxybenzoate $(0.1 \%$ and $0.5 \%), p$-hydroxybenzoic acid methyl esther $(0.5 \%)$, peracetic acid $(80 \mathrm{ppm})$, sodium hypochlorite $(100 \mathrm{ppm})$, potassium nitrate $(100 \mathrm{ppm})$, or tri-sodium tri-metaphosphate $(0.5 \%)$ reduced viable counts of listeria below detection limits upon application of the immersion treatment and/or further storage for $24 \mathrm{~h}$. A lower increase of AS-48 activity was noticed for hexadecylpyridinium chloride $(0.5 \%)$, sodium thiosulphate $(0.01 \mathrm{~N})$, tri-sodium phosphate $(1.5 \%)$ and potassium permanganate (25 ppm). This study provided a variety of combinations of enterocin AS-48 and sanitizers that improved the efficacy for decontamination of Listeria while at the same time decreasing the effective concentration of sanitizers to be added.

Since most foods (including sprouts) are complex ecosystems where mixed microbial populations coexist, the impact of bacteriocin treatment was investigated on soybean sprouts during storage at $10^{\circ} \mathrm{C}$. Changes in microbial populations during storage of bacteriocin-treated foods may provide insights on the global impact of bacteriocin treatment in addition to the selective inhibition of the bacterial pathogen being studied by selective counting methods. For doing these studies, culture-independent methods based on the total DNA of the bacterial community are frequently used, and the results of amplification of species-specific DNA regions are analysed by denaturing gel electrophoresis (DGGE). Results from sprout samples treated with enterocin AS-48 revealed modifications of the microbial populations during storage, apparently increasing the proportion of Enterococcus and Leuconostoc bacteria and decreasing the levels of Gram-negative bacteria (such as Pantoea, Escherichia and Enterobacter) on the sprouts during storage (Cobo Molinos et al., $2009 \mathrm{~b})$. These results indicate that bacteriocin treatment with enterocin AS- 48 has additional effects besides inhibition of L. monocytogenes on sprouts, disturbing the microbial balance. The consequences of these changes for the biopreservation of sprouts and for the survival of pathogenic and spoilage bacteria need to be investigated in deeper details.

Bacillus cereus is a toxin-producing common soil inhabitant that is often present in a variety of foods, including those of vegetable origin (Granum, 2001). In soybean sprouts, endospore-forming bacteria were found in the order of $2 \log \mathrm{CFU} / \mathrm{g}$, and 53 out of $55 \mathrm{~B}$. cereus isolates were found to produce diarrheic enterotoxins (Kim et al., 2004). A study was carried out on application of a washing treatment with enterocin AS- $48(25 \mu \mathrm{g} / \mathrm{ml})$ for decontamination of sprouts and green asparagus challenged with $B$. cereus and Bacillus weihenstephanensis and stored at temperatures of 6,15 or $22^{\circ} \mathrm{C}$ (Cobo Molinos et al., 2008a). The best results were obtained for samples refrigerated at $6{ }^{\circ} \mathrm{C}$, in which the washing treatments reduced the population of $B$. cereus by 1 to $1.6 \log$ cycles, and the remaining viable population was reduced below detection levels after days 1 to 3 of storage. By contrast, reductions of viable cell counts obtained after treatments at 15 or $22{ }^{\circ} \mathrm{C}$ were much lower in the three types of food tested, and the remaining viable cells multiplied during 
storage of the treated samples. A similar trend was observed for samples challenged with $B$. weihenstephanensis, with reductions of viable counts up to $3.4 \log$ cycles after treatment, complete inhibition of outgrowth during storage at $6^{\circ} \mathrm{C}$ for up to 7 days, and proliferation of survivors during storage at 15 and $22^{\circ} \mathrm{C}$. In order to improve the efficacy of treatments, the bacteriocin $(25 \mu \mathrm{g} / \mathrm{ml})$ was tested in combination with a variety of chemicals (lactic acid, sodium lactate, sodium hypochlorite, tri-sodium tri-metaphosphate, hexadecylpyridinium chloride, peracetic acid, polyphosphoric acid, carvacrol, hydrocinnamic acid, n-propyl $p$ hydroxybenzoate and $p$-hydroxybenzoic acid methyl esther) against $B$. cereus in alfalfa sprouts stored at $15^{\circ} \mathrm{C}$ (Cobo Molinos et al., 2008a; Table 1). The bactericidal effect of treatments was enhanced significantly by addition of AS- 48 for carvacrol $(0.3 \%)$, cinnamic acid $(0.3 \%)$, hydrocinnamic acid $(0.5 \%)$, polyphosphoric acid (at 0.1 and $0.5 \%)$, peracetic acid (40 ppm), hexadecylpyridinium chloride $(0.5 \%)$, sodium hypochlorite (100 ppm), and tri-sodium tri-metaphosphate $(0.5 \%)$. Interestingly, for some of the combined treatments with AS-49 (with sodium hypochlorite, peracetic acid, polyphosphoric acid, and hydrocinnamic acid) the levels of $B$. cereus remained below detection limit after $24 \mathrm{~h}$ of treatment, indicating that treatments were effective in preventing outgrowth of possible survivors or that no surviving cells were left by the treatments. The degree of protection afforded by these combined treatments was tested in alfalfa sprouts challenged with $B$. cereus and with $B$. weihenstephanensis, and stored at $15^{\circ} \mathrm{C}$ for one week. In samples treated with carvacrol, cinnamic and hydrocinnamic acids in combination with AS-48, viable cell counts of $B$. cereus remained significantly lower compared to each individual treatment during most part or the whole storage period. The best results were obtained for the combinations of AS- 48 and sodium hypochlorite, hexadecylpyridinium chloride, peracetic acid and polyphosphoric acid, which reduced the population of B. cereus below detection limits for the whole or at least most of the storage period. The combinations of $25 \mu \mathrm{g} / \mathrm{ml}$ AS48 and hydrocinnamic acid, peracetic acid, sodium hypochlorite, polyphosphoric acid and hexadecylpyridinium chloride also reduced the population of $B$. weihenstephanensis below detection limits for one week when tested on alfalfa sprouts (Cobo Molinos et al., 2008a).

Bacteriocins from Gram-positive bacteria are usually not active against Gram-negative bacteria, with some exceptions. However, Gram-negative cells can be rendered sensitive to these bacteriocins when exposed to treatments that damage the bacterial outer membrane, which acts as a barrier against diffusion of bacteriocin molecules to the cytoplasmic membrane where they exert their lethal action. Exposure to chelating agents, acids, or sublethal heat, are often used to sensitize Gram-negative bacteria to bacteriocins. Since most of the Gram-negative bacteria are resistant to enterocin AS-48, the bacteriocin was tested on sprouts in combination with several sensitizing treatments. Once the synergistic effects were demonstrated in washing treatments against S. enterica as test organism, they were corroborated on other Gram-negative species. Inactivation of S. enterica cells inoculated on soybean sprouts increased greatly when sprouts were heated for $5 \mathrm{~min}$ at $65^{\circ} \mathrm{C}$ in an alkaline solution $(25 \mu \mathrm{g} / \mathrm{ml}, \mathrm{pH}$ 9.0) of enterocin AS-48 (Cobo Molinos et al., 2008b). Washing treatments containing AS-48 $(25 \mu \mathrm{g} / \mathrm{ml})$ and 1.5\% lactic acid, 1.5\% trisodium phosphate, $0.5 \%$ trisodium tri-metaphosphate, $0.1 \%$ polyphosphoric acid, $80 \mathrm{ppm}$ peracetic acid, $0.5 \%$ hexadecylpyridinium chloride, $100 \mathrm{ppm}$ sodium hypochlorite, $0.5 \%$ n-propyl $p$ hydroxybenzoate, $0.5 \%$ p-hydroxybenzoic acid methyl esther and $2 \%$ hydrocinnamic acid significantly reduced the population of $S$. enterica to a much greater extent that the single treatments (Table 1). The best results were obtained for combinations of AS-48 and lactic acid, peracetic acid, as well as polyphosphoric acid. 


\begin{tabular}{|l|c|c|c|}
\hline & L. monocytogenes & B. cereus & S. enterica \\
\hline Acetic acid & $\mathrm{X}$ & & \\
\hline Citric acid & $\mathrm{X}$ & & \\
\hline Propionate & $\mathrm{X}$ & & \\
\hline Sorbate & $\mathrm{X}$ & $\mathrm{X}$ & $\mathrm{X}$ \\
\hline Lactic acid & $\mathrm{X}$ & $\mathrm{X}$ & $\mathrm{X}$ \\
\hline Lactate & $\mathrm{X}$ & & \\
\hline Nitrite & $\mathrm{X}$ & & \\
\hline Nitrate & & & $\mathrm{X}$ \\
\hline EDTA & $\mathrm{X}$ & $\mathrm{X}$ & $\mathrm{X}$ \\
\hline Tri-sodium phosphate & $\mathrm{X}$ & & \\
\hline Tri-sodium tri-metaphosphate & $\mathrm{X}$ & & \\
\hline Thiosulphate & $\mathrm{X}$ & $\mathrm{X}$ & $\mathrm{X}$ \\
\hline Permanganate & $\mathrm{X}$ & $\mathrm{X}$ & $\mathrm{X}$ \\
\hline Propyl-p-hydroxybenzoate & $\mathrm{X}$ & $\mathrm{X}$ & $\mathrm{X}$ \\
\hline $\begin{array}{l}\text { p-Hydoxybenzoic acid methyl } \\
\text { esther }\end{array}$ & $\mathrm{X}$ & $\mathrm{X}$ & $\mathrm{X}$ \\
\hline Peracetic acid & & $\mathrm{X}$ & $\mathrm{X}$ \\
\hline Hexadecylpyridinium chloride & & $\mathrm{X}$ & $\mathrm{X}$ \\
\hline Sodium hypochlorite & & $\mathrm{X}$ & \\
\hline Polyphosphoric acid & & $\mathrm{X}$ \\
\hline Carvacrol & & & \\
\hline Cinnamic acid & & & \\
\hline Hydrocinnamic acid & & & \\
\hline
\end{tabular}

Table 1. Antimicrobials that potentiate the efficacy of enterocin AS-48 on sprouts (X). Unmarked combinations were not tested or did not potentiate bacteriocin activity.

The efficacy of enterocin AS-48-polyphosphoric acid treatment for decontamination of sprouts was tested on other Gram-negative bacteria, including species involved in human disease and in food spoilage E. coli O157:H7, Shigella flexneri, Shigella sonnei, Enterobacter aerogenes, Y. enterocolitica, A. hydrophila and P. fluorescens). Enterocin addition increased the bactericidal effects of treatments in all cases, although there were large differences in the concentrations of polyphosphoric acid required for a complete inactivation and prolonged protection from one bacterial species to another. For example, E. coli required at least $0.4 \%$ polyphosphoric acid for complete inactivation while $Y$. enterocolitica was very sensitive to low polyphosphoric acid treatment $(0.1-0.2 \%)$. A. hydrophila and E. aerogenes were very sensitive to combined treatments with enterocin AS- 48 plus $0.5 \%$ and $1 \%$ polyphosphoric acid, respectively. $P$. fluorescens was also very sensitive to $1 \%$ polyphosphoric acid (with an average decrease of $5 \log \mathrm{CFU} / \mathrm{g}$ after the combined treatment), but it required a higher concentration of at least $2 \%$ to avoid overgrowth during storage. The shigellae were the most resistant of all bacteria to the combined treatment. S. sonnei was not completely eliminated by treatments containing $2 \%$ polyphosphoric acid and S. flexneri was even more resistant, although the combined treatment with $2 \%$ polyphosphoric acid always reduced the surviving fraction and avoided overgrwth during storage of the samples. These results suggest that combined treatments with polyphosphoric acid at $1 \%$ are sufficient to suppress the most common Gram-negative pathogens found in sprouts (that is, S. enterica and E. coli) 
as well as others such as Y. enterocolitica and the spoilage Pseudomonas. Other bacteria which are much less common, such as the shigella, would require a polyphosphoric acid concentration of at least $2 \%$ for inactivation on sprouts. Therefore, the disinfection capacity of the combined washing treatments could be adjusted depending on the estimated risks.

The bacteriocins from Gram-negative bacteria have seldom been exploited in food preservation, although they could be useful in the control of enteric pathogens. Many Gramnegative species have shown to produce bacteriocins, but those produced by E. coli strains (or colicins) have been studied in greater details (Riley and Gordon, 1996). A recently isolated E. coli strain Hu194 (from a human fecal sample) was capable of inhibiting 22 E. coli strains of serotype O157:H7 and it also exhibited some degree of antimicrobial activity against Salmonella. This inhibition was mediated by the production of a colicin named Hu194 (Nandiwada et al., 2004). Semi-crude colicin Hu194 was applied by mixing and drying on alfalfa seeds challenged with three different E. coli O157:H7 strains. The bacteriocin treatment caused variable effects depending on the strain. One of the strains was successfully inactivated (5 log CFU/g reduction) from inoculated alfalfa seeds, without any bacterial overgrowth being observed for up to 5 days of further incubation. By contrast, the other two strains required 20-fold higher colicin concentrations to achieve a reduction of $3 \mathrm{log}$ cycles (Nandiwada et al., 2004). This reduction was slightly enhanced after soaking the inoculated seeds for a longer period of time, and the maximum bacterial reduction was typically observed during the first 2 days after soaking the seeds in the colicin extract suspension. The variations observed in strain sensitivity need to be further investigated by testing a larger number of strains in order to establish the minimum bacteriocin dose that is needed to achieve an acceptable reduction of viable counts for the target bacteria.

\section{Conclusions and perspectives}

Biocontrol strategies aimed at reducing the transmission of human pathogenic bacteria through the consumption of sprouts seem a promising alternative strategy to the use of chemical preservatives or at least to reduce the concentrations of preservatives to be used. Application of live bacterial cultures requires a careful selection of strains that are well adapted to the food substrate and storage temperature of sprouts, and is somehow limited by their capacity for an effective in situ production of antimicrobial substances and/or competitive exclusion of the pathogens. Strains of Gram-negative bacteria belonging to Pseudomonas and Enterobacter genera seem to be promising for the control of Salmonella on sprouts. Intervention strategies based on lytic bacteriophages require a careful selection of complex phage preparations in order to overcome efficacy limitations due to strain specificity. Bacteriophages may act synergistically with antagonistic bacteria against selected human pathogenic bacteria. This is an interesting approach that has very seldom been exploited and where further studies are required. The lytic enzymes produced by bacteriophages could also be exploited as antimicrobial agents on sprouts (either alone or in combination with other treatments), minimizing the impact of phage specificity. However, this approach has not been investigated yet. Some bacteriocins (especially those produced by the lactic acid bacteria) have shown interesting results when tested on sprouts. The efficacy of these bacteriocins can be enhanced in combination with other antimicrobials, decreasing the concentrations of chemical preservatives required for disinfection of sprouts and protection from bacterial overgrowth during shelf life storage. The application of bacteriocins from Gram-negative bacteria for biopreservation of sprouts has been seldom 
investigated. This is an interesting field for new research as well. In addition, the application of cocktails based on protective cultures, bacteriophages and bacteriocins should also be investigated as broad-spectrum intervention strategies capable of simultaneous inhibition of mixed bacterial populations of human pathogenic bacteria on sprouts.

\section{References}

Abriouel, H.; Valdivia, E.; Martínez-Bueno, M.; Maqueda, M. \& Gálvez, A. (2003). A simple method for semi-preparative-scale production and recovery of enterocin AS-48 derived from Enterococcus faecalis subsp. liquefaciens A-48-32. Journal of Microbiological Methods, 55 (2), 599-605, ISSN 0167-7012

Abriouel, H.; Lucas, R.; Ben Omar, N.; Valdivia, E. \& Gálvez, A. (2010). Potential applications of the cyclic peptide enterocin AS-48 in the preservation of vegetable foods and beverages. Probiotics and Antimicrobial Proteins, 2(2), 77-89, ISSN 18671306

Ananou, S.; Garriga, M.; Hugas, M.; Maqueda, M.; Martínez-Bueno, M.; Gálvez, A. \& Valdivia, E. (2005) Control of Listeria monocytogenes in model sausages by enterocin AS-48. International Journal of Food Microbiology, 103 (2), 179-190, ISSN 0740-0020

Ananou, S.; Muñoz, A.; Martínez-Bueno, M.; González-Tello, P.; Gálvez, A.; Maqueda, M. \& Valdivia, E. (2010). Evaluation of an enterocin AS-48 enriched bioactive powder obtained by spray drying. Food Microbiology, 27 (1) 58-63, ISSN 0740-0020

Andrews, W.H.; Mislivec, P.B.; Wilson, C.R.; Bruce, V.R.; Polema, P.L.; Gibson, R.; Trucksess, M.W. \& Young, K. (1982). Microbial hazards associated with bean sprouting. Journal of Association of Official Analytical Chemists, 65 (2), 241-248, ISSN 1060-3271

Bari, M.L.; Ukuku, D.O.; Kawasaki, T.; Inatsu, Y.; Isshiki, K. \& Kawamoto, S. (2005). Combined efficacy of nisin and pediocin with sodium lactate, citric acid, phytic acid, and potassium sorbate and EDTA in reducing the Listeria monocytogenes population of inoculated fresh-cut produce. Journal of food protection, 68 (7), 13811387, ISSN 0362-028X

Bennik, M.H.J.; Overbeek, W. van; Smid, E.J. \& Gorris, L.G.M. (1999). Biopreservation in modified atmosphere stored mungbean sprouts: the use of vegetable-associated bacteriocinogenic lactic acid bacteria to control the growth of Listeria monocytogenes. Letters in Applied Microbiology, 28 (3), 226-232, ISSN 0266-8254

Beuchat, L.R. (1996). Pathogenic microorganisms associated with fresh produce. Journal of food protection, 59 (2), 204-216, ISSN 0362-028X

Cai, Y.; Ng, L.-K. \& Farber, J. M. (1997). Isolation and characterization of nisin-producing Lactococcus lactis subsp. lactis from bean sprouts. Journal of Applied Microbiology, 83 (4), 499-507, ISSN 1364-5072

Charkowski, A.O.; Barak, J.D.; Sarreal, C.Z. \& Mandrell, RE. (2002). Differences in growth of Salmonella enterica and Escherichia coli O157:H7 on alfalfa sprouts. Applied and Environmental Microbiology, 68 (6), 3114-3120, ISSN 0099-2240

Cobo Molinos, A.; Abriouel, H.; Ben Omar, N.; Valdivia, E.; Lucas, R.; Maqueda, M.; Martínez Cañamero, M. \& Gálvez, A. (2005). Effect of immersion solutions 
containing enterocin AS-48 on Listeria monocytogenes in vegetable foods. Applied and Environmental Microbiology, 71 (12), 7781-7787, ISSN 0099-2240

Cobo Molinos, A.; Abriouel, H.; Lucas, R.; Ben Omar, N.; Valdivia, E. \& Gálvez, A. (2008a). Inhibition of Bacillus cereus and $B$. weihenstephanensis in raw vegetables by application of washing solutions containing enterocin AS-48 alone and in combination with other antimicrobials. Food Microbiology, 25 (6), 762-770, ISSN 0740-0020

Cobo Molinos, A.; Abriouel, H.; Lucas, R.; Valdivia, E.; Ben Omar, N. \& Gálvez, A. (2008b). Combined physico-chemical treatments based on enterocin AS-48 for inactivation of Gram-negative bacteria in soybean sprouts. Food and Chemical Toxicology, 46 (6), 2912-2921, ISSN 0278-6915

Cobo Molinos, A.; Abriouel, H.; Ben Omar, N.; Lucas, R.; Valdivia, E. \& Gálvez, A. (2009a). Enhanced bactericidal activity of enterocin AS-48 in combination with essential oils, natural bioactive compounds, and chemical preservatives against Listeria monocytogenes in ready-to-eat salads. Food and Chemical Toxicology, 47 (9), 2216-2223, ISSN 0278-6915

Cobo Molinos, A., Abriouel, H.; Ben Omar, N.; Lucas, R. \& Gálvez, A. (2009b). Microbial diversity changes in soybean sprouts treated with enterocin AS-48. Food Microbiology, 26 (8) 922-926, ISSN 0740-0020

Cooley, M.B.; Miller, W.G. \& Mandrell, R.E. (2003). Colonization of Arabidopsis thaliana with Salmonella enterica and enterohemorrhagic Escherichia coli O157:H7 and competition by Enterobacter asburiae. Applied and Environmental Microbiology, 69 (8), 4915-4926, ISSN 0099-2240

Feng, G.; Guron, G.K.; Churey, J.J. \& Worobo, R.W. (2009). Characterization of mundticin L, a Class IIa anti-Listeria bacteriocin from Enterococcus mundtii CUGF08. Applied and Environmental Microbiology, 75 (17), 5708-5713, ISSN 0099-2240

Fett, W. F. (2006). Inhibition of Salmonella enterica by plant-associated pseudomonads in vitro and on sprouting alfalfa seed. Journal of Food Protection, 69 (4), 719-728, ISSN 0362-028X

Fu, T.; Stewart, D.; Reineke, K.; Ulaszek, J.; Schliesser, J. \& Tortorello, M. (2001). Use of spent irrigation water for microbiological analysis of alfalfa sprouts. Journal of Food Protection, 64 (6), 802-806, ISSN 0362-028X

Gálvez, A.; Abriouel, H.; Lucas López, R. \& Ben Omar, N. (2007). Bacteriocin-based strategies for food biopreservation. International Journal of Food Microbiology, 120 (12), 51-70, ISSN 0168-1605

Galvez, A.; Lopez, R.L.; Abriouel, H.; Valdivia, E. \& Ben Omar, N. (2008). Application of bacteriocins in the control of foodborne pathogenic and spoilage bacteria. Critical Reviews Biotechnology, 28 (2), 125-152, ISSN 0738-8551

Grande, M.J.; Lucas, R.; Abriouel, H.; Valdivia, E.; Ben Omar, N.; Maqueda, M.; MartínezBueno, M.; Martínez-Cañamero, M. \& Gálvez, A. (2006). Inhibition of toxicogenic Bacillus cereus in rice-based foods by enterocin AS-48. International Journal of Food Microbiology, 106 (2), 185-194, ISSN 0168-1605

Grande, M.J.; Lucas, R.; Abriouel, H.; Valdivia, E.; Ben Omar, N.; Maqueda, M.; MartínezCañamero, M. \& Gálvez, A. (2007a). Treatment of vegetable sauces with enterocin 
AS-48 alone or in combination with phenolic compounds to inhibit proliferation of Staphylococcus aureus. Journal of Food Protection, 70 (2), 405-411, ISSN 0362-028X

Grande, M.J.; Abriouel, H.; Lucas, R.; Valdivia, E.; Ben Omar, N.; Martínez-Cañamero, M. \& Gálvez, A. (2007b). Efficacy of enterocin AS-48 against bacilli in ready-to-eat vegetable soups and purees. Journal of Food Protection, 70 (10), 2339-2345, ISSN 0362$028 \mathrm{X}$

Granum, P.E. (2007). Bacillus cereus. In: Food Microbiology. Fundamentals and Frontiers, (third edn), Doyle, M.P. \& Beuchat, L.R. (Eds.), pp. 445-455, ASM Press, ISBN 978-1-55581407-6, Washington, DC

Greer, G.G. (2005). Bacteriophage control of foodborne bacteria. Journal of Food Protection, 68 (5), 1102-1111, ISSN 0362-028X

Harris, L.J.; Farber, J.N.; Beuchat, L.R.; Parish, M.E.; Suslow, T.V.; Garrett, E.H. \& Busta, F.F. (2003). Outbreaks associated with fresh produce: incidence, growth, and survival of pathogens in fresh and fresh-cut produce. Comprehensive Reviews in Food Science and Food Safety, 2 (Supplement), 78-141, ISSN 1541-4337

Hudson, J.A.; Billington, C.; Carey-Smith, G. \& Greening, G. (2005). Bacteriophages as biocontrol agents in food. Journal of Food Protection, 68 (2), 426-437, ISSN 0362-028X

Itoh, Y.; Sugita-Konishi, Y.; Kasuga, F.; Iwaki, M.; Hara-Kudo, Y.; Saito, N.; Noguchi, Y.; Konuma, H. \& Kumagai, S. (1998). Enterohemorrhagic Escherichia coli O157:H7 present in radish sprouts. Applied and Environmental Microbiology, 64 (4), 1532-1535, ISSN 0099-2240

Jack, R.W.; Tagg, J.R. \& Ray, B. (1995) Bacteriocins of Gram positive bacteria. Microbiology Reviews, 59 (2), 171-200, ISSN 0146-0749

Kawamoto, S.; Shima, J.; Sato, R.; Eguchi, T.; Ohmomo, S.; Shibato, J.; Horikoshi, N.; Takeshita, K. \& Sameshima, T. (2002). Biochemical and genetic characterization of mundticin KS, an antilisterial peptide produced by Enterococcus mundtii NFRI 7393. Applied and Environmental Microbiology, 68 (8), 3830-3840, ISSN 0099-2240

Kim, H.J.; Lee, D.S. \& Paik, H.D. (2004). Characterization of Bacillus cereus isolates from raw soybean sprouts. Journal of Food Protection, 67 (5), 1031-1035, ISSN 0362-028X

Kocharunchitt, C.; Ross, T. \& McNeil, D.L. (2009). Use of bacteriophages as biocontrol agents to control Salmonella associated with seed sprouts. International Journal of Food Microbiology, 128 (3), 453-459, ISSN 0168-1605

Liao, C.H. (2008). Growth of Salmonella on sprouting alfalfa seeds as affected by the inoculum size, native microbial load and Pseudomonas fluorescens 2-79. Letters in Applied Microbiology, 46 (2), 232-6, ISSN 0266-8254

Liao, C.-H. \& Fett, W.F. (2001). Analysis of native microflora and selection of strains antagonistic to human pathogens on fresh produce. Journal of Food Protection, 64 (8), 1110-1115, ISSN 0362-028X

Lynch, M.F.; Tauxe, R.V. \& Herberg, C.W. (2009). The growing burden of foodborne outbreaks due to contaminated fresh produce: risks and opportunities. Epidemiology and Infection, 137 (3), 307-315, ISSN 0950-2688

Maqueda, M.; Gálvez, A.; Martínez Bueno, M.; Sanchez-Barrena, M.J.; González, C.; Albert, A.; Rico, M. \& Valdivia, E. (2004). Peptide AS-48: prototype of a new class of cyclic bacteriocins. Current Protein \& Peptide Science, 5 (5), 399-416, ISSN 1389-2037 
Martínez-Viedma, P.; Sobrino, A.; Ben Omar, N.; Abriouel, H.; Lucas López, R.; Valdivia, E.; Martín Belloso, O. \& Gálvez, A. (2008). Enhanced bactericidal effect of HighIntensity Pulsed-Electric Field treatment in combination with enterocin AS-48 against Salmonella enterica in apple juice. International Journal of Food Microbiology, 128 (2), 244-249, ISSN 0168-1605

Martínez-Viedma, P.; Abriouel, H.; Ben Omar, N.; Lucas, R.; Valdivia, E. \& Gálvez, A. (2009a). Inactivation of Geobacillus stearothermophilus in canned foods and drinks by addition of enterocin AS-48. Food Microbiology, 26 (3), 289-293, ISSN 0740-0020

Martínez-Viedma, P.; Abriouel, H.; Sobrino, A.; Ben Omar, N.; Lucas López, R.; Valdivia, E.; Martín Belloso, O. \& Gálvez, A. (2009b). Effect of enterocin AS-48 in combination with High-Intensity Pulsed-Electric Field treatment against the spoilage bacterium Lactobacillus diolivorans in apple juice. Food Microbiology, 26 (5), 491-496, ISSN 0740-0020

Matos, A. \& Garland, J.L. (2005). Effects of Community Versus Single Strain Inoculants on the biocontrol of Salmonella and microbial community dynamics in alfalfa sprouts. Journal of Food Protection, 68 (1), 40-48, ISSN 0362-028X

Muñoz, A.; Ananou, S.; Gálvez, A.; Martínez-Bueno, M.; Rodríguez, A.; Maqueda, M. \& Valdivia, E. (2007). Inhibition of Staphylococcus aureus in dairy products by enterocin AS-48 produced in situ and ex situ: bactericidal synergism with heat. International Dairy Journal, 17 (7), 760-769, ISSN 0958-6946

Nandiwada, L.S.; Schamberger, G.P.; Schafer, H.W. \& Diez-Gonzalez, F. (2004). Characterization of an E2-type colicin and its application to treat alfalfa seeds to reduce Escherichia coli O157:H7. International Journal of Food Microbiology, 93 (3), 267279, ISSN 0168-1605

Pao, S.; Rolph, S.P.; Westbrook, E.W. \& Shen, H. (2004). Use of bacteriophages to control Salmonella in experimentally contaminated sprout seeds. Journal of Food Science, 69 (5), 127-130, ISSN 0022-1147

Patterson, J.E. \& Woodburn, M.J. (1980). Klebsiella and other bacteria on alfalfa and bean sprouts at the retail level. Journal of Food Science, 45 (3), 492-495, ISSN 0022-1147

Prokopowich, D. \& Blank, G. (1991). Microbiological evaluation of vegetable sprouts and seeds. Journal of Food Protection, 54 (7), 560-562, ISSN 0362-028X

Rees, C.E.D. \& Dodd, C.E.R. (2006). Phage for rapid detection and control of bacterial pathogens in food. Advances in Applied Microbiology, 59, 159-186, ISSN 0065-2164

Riley, M.A. \& Gordon, D.M. (1996). The ecology and evolution of bacteriocins. Journal of Industrial Microbiology, 17 (3-4), 151- 158, ISSN 1367-5435

Robertson, L.J.; Johannessen, G.S.; Gjerde, B.K. \& Loncarevic, S. (2002). Microbiological analysis of seed sprouts in Norway. International Journal of Food Microbiology, 75 (12), 119-126, ISSN 0168-1605

Rosas, C.J. \& E.F. Escartin. (2000). Survival and growth of Vibrio cholerae O1, Salmonella typhi and Escherichia coli O157:H7 in alfalfa sprouts. Journal of Food Science, 65 (1), 162 165, ISSN 0022-1147

Splittstoesser, D.F.; Queale, D.T. \& Andaloro, B.W. (1983). The microbiology of vegetable sprouts during commercial production. Journal of Food Safety, 5 (2), 79-86, ISSN 0149-6085 
Taormina, P.J.; Beuchat, L.R. \& Slutsker, L. (1999). Infections associated with eating seed sprouts: an international concern. Emerging Infectious Diseases, 5 (5), 626- 634, ISSN 1080-6040

Weiss, A.; Hertel, C.; Grothe, S.; Ha, D. \& Hammes, W.P. (2007). Characterization of the cultivable microbiota of sprouts and their potential for application as protective cultures. Systematic and Applied Microbiology, 30 (6), 483-93, ISSN 0723-2020

Ye, J.; Kostrzynska, M.; Dunfield, K. \& Warriner, K. (2010). Control of Salmonella on sprouting mung bean and alfalfa seeds by using a biocontrol preparation based on antagonistic bacteria and lytic bacteriophages. Journal of Food Protection, 73 (1), 9-17, ISSN 0362-028X 


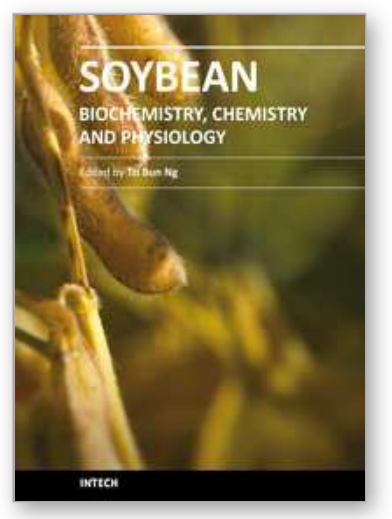

\section{Soybean - Biochemistry, Chemistry and Physiology \\ Edited by Prof. Tzi-Bun Ng}

ISBN 978-953-307-219-7

Hard cover, 642 pages

Publisher InTech

Published online 26, April, 2011

Published in print edition April, 2011

Soybean is an agricultural crop of tremendous economic importance. Soybean and food items derived from it form dietary components of numerous people, especially those living in the Orient. The health benefits of soybean have attracted the attention of nutritionists as well as common people.

\section{How to reference}

In order to correctly reference this scholarly work, feel free to copy and paste the following:

Antonio Gálvez, Hikmate Abriouel, Antonio Cobo and Rubén Pérez Pulido (2011). Natural Antimicrobials for Biopreservation of Sprouts, Soybean - Biochemistry, Chemistry and Physiology, Prof. Tzi-Bun Ng (Ed.), ISBN: 978-953-307-219-7, InTech, Available from: http://www.intechopen.com/books/soybean-biochemistrychemistry-and-physiology/natural-antimicrobials-for-biopreservation-of-sprouts

\section{INTECH}

open science | open minds

\section{InTech Europe}

University Campus STeP Ri

Slavka Krautzeka 83/A

51000 Rijeka, Croatia

Phone: +385 (51) 770447

Fax: +385 (51) 686166

www.intechopen.com

\section{InTech China}

Unit 405, Office Block, Hotel Equatorial Shanghai

No.65, Yan An Road (West), Shanghai, 200040, China 中国上海市延安西路65号上海国际贵都大饭店办公楼 405 单元

Phone: +86-21-62489820

Fax: $+86-21-62489821$ 
(C) 2011 The Author(s). Licensee IntechOpen. This chapter is distributed under the terms of the Creative Commons Attribution-NonCommercialShareAlike-3.0 License, which permits use, distribution and reproduction for non-commercial purposes, provided the original is properly cited and derivative works building on this content are distributed under the same license. 